\title{
CHEMICAL AND SENSORY CHARACTERISTICS OF CARP MEAT (Osphronemus goramy) FROM DIFFERENT SIZES
}

\section{KARAKTERISTIK KIMIA DAN SENSORIS DAGING IKAN GURAMI (Osphronemus gouramy) DARI UKURAN BERBEDA}

\author{
Guswanda Putra ${ }^{1}$, Bustari Hasan ${ }^{2}$, Sumarto $^{2}$ \\ 1Teknologi Hasil Perikanan Fakultas Perikanan dan Kelautan Universitas Riau, Pekanbaru, Jl. HR Soebrantas Km 12,5 \\ Simpang Baru, Panam - Pekanbaru, Indonesia 28293. \\ 2Teknologi Hasil Perikanan Fakultas Perikanan dan Kelautan Universitas Riau, Pekanbaru, Jl. HR Soebrantas Km 12,5 \\ Simpang Baru, Panam - Pekanbaru, Indonesia 28293. \\ Correspondence Author : sumarto1976@yahoo.co.id
}

\begin{tabular}{|c|c|}
\hline $\mathrm{L}$ & $\mathrm{B}$ \\
\hline $\begin{array}{l}\text { Diterima: } 2 \text { Desember } 2018 \\
\text { Disetujui: } 16 \text { Januari } 2019\end{array}$ & $\begin{array}{l}\text { This research aims to evaluate and compare of proximate composition, amino acid } \\
\text { and fatty acid of carp (Osphronemus goramy) from different sizes: small (400-500 }\end{array}$ \\
\hline $\begin{array}{l}\text { Kata kunci: } \\
\text { osphronemus, gouramy, } \\
\text { gourami fish, chemistry, } \\
\text { sensory, different size }\end{array}$ & $\begin{array}{l}\text { gr), medium }(600-800 \mathrm{~g}) \text {, and large }(900-1100 \mathrm{~g}) .27 \text { samples of carp were } \\
\text { obtained from a cage in Gurami village, Kampar. The edible portion, processing } \\
\text { waste, water holding capacity, sensory quality, proximate, amino acid and fatty } \\
\text { acid were evaluated. The result showed that appearance, odor, edible portion, } \\
\text { processing waste were not different between fish sizes. The highest taste and } \\
\text { texture were found in large size carp }(8.5 \text { and } 8.1) \text {, then followed by medium }(8.3 \\
\text { and } 7.9) \text {, and small }(7.6 \text { and } 7.8) \text {, respectively. The highest water holding capacity } \\
\text { was found in medium size carp }(32.4 \%) \text { then large }(28.3 \%) \text { and small }(26.0 \%) \text {. The } \\
\text { result of proximate analysis of the highest water and ash content were found in } \\
\text { small size carp }(75.55 \% \text { and } 1.05 \%) \text {, then followed by medium ( } 74.20 \% \text { and } \\
0.90 \%) \text { and large }(7.69 \% \text { and } 0.88 \%) \text {. The protein content of large size carp } \\
\text { (20.88\%) was higher than medium }(18.70 \%) \text { and small }(18.36 \%) \text {. The fat content } \\
\text { of large size carp }(2.70 \%) \text { was higher than medium }(2.40 \%) \text { and small }(2.29 \%) \text {. } \\
\text { The highest amino acid was found in large size carp }(69.25 \%) \text { followed by medium } \\
(56.38 \%) \text { and small }(49.86 \%) \text {. The highest fatty acid was found in large size carp } \\
(99.55 \%) \text { followed by small }(97.63 \%) \text { and medium }(97.20 \%) \text {. }\end{array}$ \\
\hline
\end{tabular}

\section{PENDAHULUAN}

Wilayah perairan Indonesia sangat luas dan memiliki sumberdaya perikanan yang cukup melimpah. Salah satu sumberdaya perikanan yang cukup besar manfaatnya yaitu perikanan darat. Perikanan darat meliputi, tawar, payau, dan budidaya. Adapun potensi produksi perikanan budidaya di Provinsi Riau menurut Data Badan Pusat Statistik menyebutkan bahwa tahun 2015, sekitar 66,97 persen produksi perikanan budidaya Provinsi Riau atau sebanyak 57.868,63 ton di sumbangkan Kabupaten Kampar. Adapun total produksi perikanan budidaya Provinsi Riau mencapai 86.406,31 ton (Kementrian Kelautan Perikanan, 2016).

Ikan gurami (Oshpronemus gouramy) merupakan ikan asli Indonesia yang berasal dari perairan Sunda Besar, setelah itu menyebar ke seluruh perairan Asia Tenggara. Ikan ini merupakan salah satu komoditi perikanan air tawar yang cukup penting apabila dilihat dari permintaannya yang cukup besar dan harganya yang relatif lebih tinggi dibandingkan dengan ikan air tawar lainnya, seperti ikan mas, 
nila, lele, dan patin. Ikan ini dipandang sebagai salah satu ikan bergengsi dan biasanya disajikan pada acara-acara yang dianggap penting.

Adapun keunggulan dari hasil perikanan, yakni ikan merupakan salah satu sumber protein hewani yang cukup tinggi dan dapat dicerna dengan mudah oleh manusia. Kandungan protein dan vitamin yang cukup tinggi juga membuat ikan sangat membantu pertumbuhan anak - anak balita, karena komposisi asam amino yang cukup lengkap serta kandungan gizinya yang bermanfaat untuk mencegah dari penyakit degeneratif, seperti jantung koroner, tekanan darah tinggi, stroke, dan kanker.

Namun demikian, kurangnya informasi mengenai kandungan gizi ikan tersebut menyebabkan sumberdaya yang tersedia belum dimanfaatkan secara optimal. Salah satu informasi penting yang belum banyak diketahui adalah komposisi protein ikan serta jenis dan jumlah asam amino, dan asam lemak yang dikandung oleh ikan gurami. Oieh karena itu, penelitian ini dilakukan untuk mengetahui kandungan gizi pada ikan gurami agar menjadi informasi bagi masyarakat luas dan rnenjadikan ikan gurami sebagai salah satu surnber makanan berprotein.

Survei di lapangan menunjukkan ukuran konsumsi ikan ini berkisar antara 900-1100 gram per ekor. Ikan ukuran ini biasanya lebih disukai oleh kebanyakan konsumen sebab memiliki daging yang tebal dan gurih. dengan demikian juga akan menentukan jenis olahan yang dapat dari ikan tersebut. Maka perlu dilakukan pengujian kimia dan sensoris ikan gurami dari ukuran berbeda.

\section{METODE PENELITIAN}

Penelitian ini telah dilaksanakan pada bulan februari-maret 2018 di Laboratorium Teknologi Hasil Perikanan, Laboratorium Kimia Hasil Perikanan, Laboratorium Terpadu Fakultas Perikanan dan Kelautan Universitas Riau Pekanbaru, Laboratorium Terpadu Institut Pertanian Bogor, IPB, dan Laboratorium Balai Besar Industri Argo Bogor.

Bahan-bahan yang digunakan dalam penelitian ini adalah ikan gurami ukuran 400-500 gr, 600-800 gr, dan 900-1100 gr per ekor yang diperoleh dari keramba nelayan di Kabupaten Kampar sebanyak 27 ekor. Bahan kimia untuk analisa proksimat (H2SO4 98\%, $\mathrm{H} 2 \mathrm{BO} 32 \%, \mathrm{NaOH} 50 \%, \mathrm{Cu}$

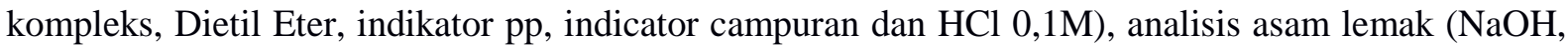
metanol, BF3, kaprat, laurat, miristat, palmitat, stearat, linoleat, linolenat, EPA, dan DHA) dan analisis asam amino (HCL, larutan deviratisasi, ortoftalaldehida, natrium hidroksida, asam borat, larutan brij $30 \%$, 2- merkaptoetanol, larutan standar asam amino, na-edta, metanol, tetrahidrofuran (THF), naasetat 5, air).

Alat yang digunakan adalah alat untuk pemfilletan ikan yaitu pisau, talenan dan baskom. Alat lainnya adalah alat-alat untuk analisis proksimat, asam lemak dan sensori yaitu : desikator, gelas ukur, labu kjeldahl, timbangan analitik, Erlenmeyer, cawan porselen, oven, labu ukur, pipet tetes, soxhlet, kertas saring, tabung reaksi, kromatografi, pena, dan kertas score sheet).

Metode yang digunakan dalam penelitian ini adalah metode eksperimen, yaitu melakukan analisis kimia dan sensoris daging ikan gurami (Osphronemus gouramy) dari ukuran berbeda. Rancangan percobaan yang digunakan adalah Rancangan Acak Lengkap satu faktorial dimana perlakuannya adalah ukuran ikan yang terdiri dari 3 taraf, yaitu : ukuran 400-500 gram (GK); ukuran 600-800 gram (GS) dan ukuran 900-1100 gram (GB) dengan 3 kali ulangan. Jumlah unit percobaan pada penelitian ini adalah 9 unit. Parameter yang diuji meliputi karekteristik fisik daging ikan (edible portion, processing waste, water holding capacity), mutu sensoris (bau, tekstur, rasa, penampakan), analisis proksimat (kadar air, kadar abu, kadar protein dan kadar lemak), asam amino dan asam lemak. Sampel yang digunakan dalam penelitian ini adalah ikan gurami ukuran 400-500 gr (G1), 600-800 gr (G2), dan 900-1100 gr (G3) per ekor yang diperoleh dari keramba nelayan di kampung Gurami di Kabupaten Kampar sebanyak 27 ekor, ikan dimasukkan kedalam styrofoam box dan diangkut ke laboratorium Teknologi Hasil Perikanan dalam keadaan hidup, kemudian ikan difillet dan isi perut, tulang, kepala, sirip ditimbang untuk menghitung edible portion, processing waste dan water holding capacity, kemudian ikan dicuci sampai benar-benar bersih setelah itu hasil fillet ikan dilakukan analisis.

\section{HASIL DAN PEMBAHASAN}

\section{Nilai Mutu Sensoris}

Secara umum nilai rata-rata sensoris secara keseluruhan daging ikan gurami (Osphronemus 
gouramy) ukuran berbeda ditampilkan pada Tabel 1. Tidak terdapat pengaruh ukuran terhadap nilai sensoris ikan gurami segar $(\mathrm{p}<0.05)$, kecuali rasa dan tekstur pada ikan berukuran besar berbeda nyata dengan ikan berukuran kecil dan sedang $(\mathrm{p}>0.05)$.

Hasil penelitian menunjukan bahwa mutu sensoris ikan gurami pada uji penampakan dan bau tidak berbeda menurut ukuran ikan karena kondisi ikan pada saat difillet masih dalam keadaan segar dan ikan belum mengalami proses penurunan mutu (proses deteriorasi) bila dilihat pada uji proksimat kadar lemak antara ukuran ikan kecil, sedang dan besar tidak terlalu jauh perbedaannya yaitu $\pm 3 \%$ sehingga proses oksidasi lemak oleh udara belum terjadi pada penampakan dan bau ikan. Tetapi untuk uji rasa dan tekstur memiliki perbedaan menurut ukuran ikan. Untuk nilai rasa dan tekstur, ikan mutu sensoris (bau, rupa, rasa, tekstur) dan daging ikan gurami dikeringkan menggunakan oven dan sampel dikirim ke Laboratorium Terpadu Institut Pertanian Bogor, IPB untuk mencari proksimat (kadar air, abu, protein, dan lemak), asam amino dan Balai Besar Industri Agro untuk mencari Asam Lemak ukuran yang besar memiliki nilai yang paling tinggi diikuti dengan ikan ukuran sedang dan ikan ukuran kecil memiliki nilai paling rendah. Ikan ukuran besar memiliki rasa enak disebabkan adanya asam amino glutamat yang tinggi pada protein serta lemak yang terkandung didalam ikan. Dan ikan ukuran besar memiliki tekstur daging yang kompak dan empuk.

\section{Edible Portion}

Persentase bagian yang dapat dimakan ikan gurami dari ukuran berbeda ditampilkan pada Tabel 2. Berat bagian yang dapat dimakan meningkat dengan semakin besar ukuran ikan, namun tidak berpengaruh nyata pada hasil persentase daging ikan $(\mathrm{p}<0.05)$.

Pada penelitian ini, edible portion yang dimanfaatkan adalah hasil daging ikan utuh setelah difillet yang dapat dimakan . Dimana selanjutnya digunakan untuk uji organoleptik, analisis asam amino, asam lemak dan analisis kadar proksimat, nilai edible portion ikan gurami pada beberapa ukuran berkisaran antara 255,1-546,6 g. Berdasarkan Tabel 2 dapat diketahui bahwa edible portion tertinggi terdapat pada ikan ukuran 900-1100 g dan yang terendah pada ikan gurami ukuran 400-500 g. Peningkatan nilai edible portion ikan tersebut dipengaruhi oleh ukuran daging dan tulang yang semakin besar. Selain itu hal ini juga tidak terlepas kaitannya terhadap makanan serta habitatnya. Menurut Hadiwiyoto (1993), edible portion ikan dipengaruhi oleh pola pertumbuhan ikan tersebut. Pertumbuhan pada ikan dipengaruhi oleh beberapa faktor diantaranya, jenis ikan, jenis kelamin, fishing ground, umur ikan, musim, dan jenis makanan yang tersedia.

Edible portion digunakan untuk menentukan berapa bagian ikan yang dapat dimanfaatkan sebagai bahan pangan. Nilai ekonomis dan efektifitas suatu produk atau bahan pangan sangat dipengaruhi oleh hasil edible portion. Semakin tinggi nilai edible portion maka nilai ekonomis juga semakin tinggi.

\section{Procesing Waste}

Persentase bagian yang tidak dapat dimakan ikan gurami dari ukuran berbeda ditampilkan pada Tabel 3. Berat bagian yang tidak dapat dimakan meningkat dengan semakin besar ukuran ikan; namun tidak berpengaruh nyata pada hasil persentase daging ikan $(\mathrm{p}<0.05)$.

Hasil penelitian menunjukan bahwa nilai Processing waste ikan gurami pada beberapa ukuran berkisaran antara 221,1 - 468,7 g. Berdasarkan Tabel 3 dapat diketahui bahwa Processing waste tertinggi terdapat pada ikan ukuran 900-1100 g dan yang terendah pada ikan gurami ukuran 400-500 g. Nilai processing waste ikan gurami ukuran besar lebih tinggi daripada sampel ikan ukuran sedang dan kecil dikarenakan isi perut dari ikan ukuran besar lebih banyak dari ikan sedang dan besar, kepala ikan ukuran besar juga lebih besar dibandingkan ikan ukuran sedang dan kecil. Limbah merupakan hasil sisa produk utama dari suatu proses yang berasal dari bahan dasar atau bahan bantu proses tersebut. Limbah juga dapat diartikan sebagai buangan yang kehadirannya pada suatu saat dan tempat tertentu tidak dikehendaki lingkungan karena tidak memiliki nilai ekonomis yang ketika mencapai jumlah atau konsentrasi tertentu, dapat menimbulkan dampak negatif bagi lingkungan (Setiyawan, 2010).

\section{Water Holding Capacity}

Nilai rata-rata daya ikat air oleh protein daging ikan gurami ukuran berbeda ditampilkan pada Tabel 4. Rata-rata daya ikat air oleh protein daging ikan gurami lebih tinggi pada ikan ukuran sedang, berbeda nyata dengan ikan ukuran besar dan kecil ( $p>0.05)$.

Hasil penelitian ini menunjukan bahwa Water holding capacity daging ikan gurami pada beberapa ukuran berkisaran antara 26,0-32,4 g. Berdasarkan Tabel 4 dapat diketahui bahwa Water holding capacity tertinggi terdapat pada ikan gurami ukuran 600-800 g, kemudian ikan ukuran 900$1100 \mathrm{~g}$ dan yang terendah pada ikan gurami ukuran 400-500 g. Daya ikat air protein daging lebih tinggi pada ikan ukuran sedang dikarenakan pada uji proksimat untuk kadar protein, nilai protein tertinggi terdapat pada ikan ukuran sedang. Warrna gelap pada daging juga berhubungan dengan daya ikat air ( water holding capacity) yang lebih tinggi dari normal, Ph daging akan mempengaruhi warna daging, daya ikat air dan keempukan daging, (Bahar, 2003). 
Tabel 1. Nilai rata-rata sensoris daging ikan gurami dari ukuran berbeda.

\begin{tabular}{lcrr}
\hline \multirow{2}{*}{ Organoleptik } & \multicolumn{3}{c}{ Ukuran ikan } \\
\cline { 2 - 4 } & GK & GS & GB \\
\hline Rupa & $9,0 \pm 0,0^{\mathrm{a}}$ & $9,0 \pm 0,0^{\mathrm{a}}$ & $9,0 \pm 0,0^{\mathrm{a}}$ \\
\hline Bau & $9,0 \pm 0,0^{\mathrm{a}}$ & $9,0 \pm 0,0^{\mathrm{a}}$ & $9,0 \pm 0,0^{\mathrm{a}}$ \\
\hline Rasa & $7,6 \pm 0,2^{\mathrm{a}}$ & $8,3 \pm 0,2^{\mathrm{b}}$ & $8,5 \pm 0,0^{\mathrm{b}}$ \\
\hline Tekstur & $7,8 \pm 0,0^{\mathrm{a}}$ & $7,9 \pm 0,2^{\mathrm{a}}$ & $8,1 \pm 0,0^{\mathrm{b}}$ \\
\hline Rata-rata & $8,3 \pm 0,2^{\mathrm{a}}$ & $8,5 \pm 0,2^{\mathrm{a}}$ & $8,6 \pm 0,0^{\mathrm{a}}$ \\
\hline Ket $: G K: 400-500 g ; G S: 600-800 g ; G B: 900-1100 \mathrm{~g}$ &
\end{tabular}

Ket: $G K: 400-500 \mathrm{~g} ; \mathrm{GS}: 600-800 \mathrm{~g} ; \mathrm{GB}: 900-1100 \mathrm{~g}$

Tabel 2. Edible portion daging ikan gurami dari ukuran berbeda.

\begin{tabular}{lccr}
\hline Ukuran ikan & $\begin{array}{c}\text { Ikan utuh } \\
\text { (gram) }\end{array}$ & $\begin{array}{c}\text { Edible portion } \\
\text { (gram) }\end{array}$ & $\begin{array}{c}\text { Persentase } \\
(\%)\end{array}$ \\
\hline GK & $485,2 \pm 15,0$ & $255,1 \pm 5,0$ & $53,3^{\mathrm{a}}$ \\
\hline GS & $765,2 \pm 15,0$ & $410,1 \pm 1,0$ & $53,2^{\mathrm{a}}$ \\
\hline GB & $1016,9 \pm 28,8$ & $546,6 \pm 20,8$ & $53,4^{\mathrm{a}}$
\end{tabular}

Tabel 3. Processing waste daging ikan gurami dari ukuran berbeda.

\begin{tabular}{llll}
\hline Ukuran ikan & $\begin{array}{l}\text { Ikan utuh } \\
\text { (gram) }\end{array}$ & $\begin{array}{l}\text { Processing } \\
\text { waste } \\
\text { (gram) }\end{array}$ & Persentase(\%) \\
\hline GK & $485,2 \pm 15,0$ & $221,1 \pm 10,0$ & $46,7^{\mathrm{a}}$ \\
\hline GS & $765,2 \pm 15,0$ & $351,1 \pm 4,0$ & $47,0^{\mathrm{a}}$ \\
\hline GB & $1016,9 \pm 28,8$ & $468,7 \pm 10,0$ & $47,7^{\mathrm{a}}$ \\
\hline
\end{tabular}

Tabel 4. Water holding capacity daging ikan gurami dari ukuran berbeda.

\begin{tabular}{lccr}
\hline & \multicolumn{3}{c}{ Ukuran ikan } \\
\hline Ulangan & GK & GS & GB \\
\hline 1 & 20,0 & 31,5 & 26,5 \\
2 & 23,9 & 33,0 & 27,0 \\
\hline 3 & 24,5 & 32,7 & 27,8 \\
\hline Rata-rata & $26,0 \pm 0,7^{\mathrm{a}}$ & $32,4 \pm 0,8^{\mathrm{b}}$ & $28,3 \pm 0,6^{\mathrm{b}}$ \\
\hline
\end{tabular}

Tabel 5. Nilai rata-rata proksimat daging ikan gurami dari ukuran berbeda.

\begin{tabular}{lcccc}
\hline $\begin{array}{l}\text { Jenis } \\
\text { sampel }\end{array}$ & Air (\%) & Abu (\%) & Protein (\%) & Lemak (\%) \\
\hline GK & $75,55 \pm 0,2^{\mathrm{c}}$ & $1,05 \pm 0,01^{\mathrm{b}}$ & $18,36 \pm 0,4^{\mathrm{a}}$ & $2,29 \pm 0,1^{\mathrm{a}}$ \\
\hline GS & $74,20 \pm 0,4^{\mathrm{b}}$ & $0,90 \pm 0,02^{\mathrm{a}}$ & $18,70 \pm 0,1^{\mathrm{a}}$ & $2,40 \pm 0,2^{\mathrm{a}}$ \\
\hline GB & $72,69 \pm 0,02^{\mathrm{a}}$ & $0,88 \pm 0,01^{\mathrm{a}}$ & $20,88 \pm 2,1^{\mathrm{b}}$ & $2,70 \pm 0,3^{\mathrm{a}}$ \\
\hline
\end{tabular}

Tabel 6. Hasil Analisis Asam Amino Ikan Gurami.

\begin{tabular}{lccc}
\hline \multirow{2}{*}{ Jenis Asam Amino } & Ukuran ikan & \multicolumn{2}{c}{ Satuan $(\%$ B/B) } \\
\cline { 2 - 4 } & GK & GS & GB \\
\hline Asam Aspartat & 4,46 & 4,79 & 7,52 \\
\hline Asam Glutamat & 9,48 & 11,16 & 14,49 \\
\hline Serin & 2,48 & 2,86 & 3,52 \\
\hline Glisin & 1,14 & 1,33 & 1,76 \\
\hline Histidin & 4,29 & 5,62 & 5,90 \\
\hline Arginin & 3,43 & 3,57 & 3,91 \\
\hline Threonin & 1,74 & 1,85 & 2,08 \\
\hline
\end{tabular}




\begin{tabular}{lccc}
\hline Alanin & 0,61 & 0,83 & 0,72 \\
\hline Prolin & 0,84 & 1,12 & 1,33 \\
\hline Tirosin & 1,11 & 1,61 & 1,75 \\
\hline Valin & 3,30 & 3,65 & 4,53 \\
\hline Methionin & 4,16 & 4,64 & 5,55 \\
\hline Sistin & 1,57 & 1,63 & 2,46 \\
\hline Isoleusin & 2,01 & 1,84 & 2,56 \\
\hline Leusin & 4,87 & 4,94 & 5,59 \\
\hline Fenilalanin & 1,96 & 2,15 & 2,85 \\
\hline Lisin & 2,42 & 2,79 & 2,73 \\
\hline Total & 49,86 & 56,38 & 69,25 \\
\hline
\end{tabular}

Tabel 7. Komposisi asam lemak daging ikan gurami ukuran kecil, sedang dan besar.

\begin{tabular}{llccc}
\hline No & Asam lemak (\%) & \multicolumn{3}{c}{ Ukuran ikan } \\
\cline { 3 - 5 } 1 & Lauric acid C12:0 & GK & GS & GB \\
\hline 2 & Myristic acid C14:0 & 2,47 & 0,34 & 0,28 \\
\hline 3 & Myristoleic acid C14:1 & 0,11 & 0,13 & 2,52 \\
\hline 4 & Pentadecanoic acid C15:0 & 0,53 & 0,49 & 0,25 \\
\hline 5 & Palmitic acid C16:0 & 22,46 & 24,78 & 22,31 \\
\hline 6 & Palmitoleic acid C16:1 & 2,47 & 2,41 & 2,96 \\
\hline 7 & Heptadecanoic acid C17:0 & 0,40 & 0,33 & 0,27 \\
\hline 8 & Heptadecenoic acid C17:1 & 0,13 & 0,21 & 0,17 \\
\hline 9 & Stearic acid C18:0 & 4,56 & 7,82 & 7,16 \\
\hline 10 & Oleic acid C18:1n9c & 35,03 & 33,25 & 33,60 \\
\hline 11 & Linoleic acid C18:2n6c & 21,60 & 16,71 & 19,29 \\
\hline 12 & Arachidic C20:0 & 0,32 & 0,32 & 0,36 \\
\hline 13 & Y-linolenic acid C18:3n6 & 2,48 & 2,59 & 2,71 \\
\hline 14 & Eicosenoic acid C20:1n9 & 0,45 & 0,35 & 0,15 \\
\hline 15 & A-linoleic acid C18:3n3 & 1,11 & 1,09 & 1,04 \\
\hline 16 & Heneicosanoic acid C21:0 & 0,59 & 0,57 & 0,54 \\
\hline 17 & Docosanoic acid C22:0 & 0,85 & 0,70 & 0,61 \\
\hline 18 & Eicosatrienoic acid C20:3n6 & 1,11 & 0,82 & 1,09 \\
\hline 19 & Erucic acid C22:1n9 & 0,40 & 0,47 & 0,40 \\
\hline 20 & Arachidonic acid C20:4n6 & 0,21 & 0,22 & 0,28 \\
\hline 21 & DHA acid C22:6n3 & 1,61 & 1,19 & 1,53 \\
\hline & Total & 97,63 & 97,20 & 99,45 \\
\hline & & & &
\end{tabular}

\section{Analisa Proksimat}

Secara umum nilai rata-rata analisis proksimat secara keseluruhan daging ikan gurami (Osphronemus gouramy) ukuran berbeda ditampilkan pada Tabel 5. Kadar air ikan gurami dengan beberapa ukuran pada table 5 berkisar 72,69-75,55 \%. Kadar air tertinggi terdapat pada ikan gurami dengan ukuran 400-500 g dan yang terendah pada ikan gurami ukuran 900-1100 g. Hal ini menunjukkan bahwa kadar air pada ikan dipengaruhi oleh perbedaan ukuran ikan yang secara tidak langsung berkaitan dengan umur panen, selain itu kadar air pada ikan berkaitan dengan kadar lemak ikan. Semakin tinggi kadar air pada ikan maka makin rendah kadar lemaknya (Suzuki, 1981). Hal ini dapat dipengaruhi oleh adanya sistem osmoregulasi yang baik pada ikan.

Kadar abu ikan gurami pada beberapa ukuran ikan berkisar antara 0,88-1,05\%. Kadar abu 
tertinggi terdapat pada ikan ukuran 400-500 g sebesar 1,05\% dan kadar abu terendah terdapat pada ikan ukuran 900-1100 g dengan nilai 0,88 \%. Kadar abu yang tinggi pada ikan gurami ukuran 400-500 g disebabkan karena rendemen tulang ikan yang cukup besar, selain itu ikan masih dalam tahap pertumbuhan, sehingga banyak terdapat komponen-komponen mineral penyusun tulang sehingga meningkatkan kandungan abu atau mineral pada ikan tersebut. Kadar mineral tulang mencapai puncaknya di awal masa dewasa, kemudian secara perlahan menurun bersama umur (Sudarmadji et al., 1989).

Kadar protein pada Tabel 5 berkisar 18,36-20,88 \%. Kadar protein tertinggi terdapat pada ikan ukuran 900-1100 g yaitu 20,88 \% dan terendah pada ikan ukuran 400-500 g dengan yaitu 18,36\%. Kandungan protein ikan semakin meningkat seiring dengan meningkatnya ukuran ikan. Semakin tinggi perubahan bobot tubuh dalam kurun waktu tertentu, maka laju pertumbuhan akan semakin tinggi. Laju pertumbuhan ini erat kaitannya dengan bobot tubuh dan bobot tubuh erat kaitannya dengan protein. Hal tersebut dimengerti karena hampir 45-75\% berat kering tubuh ikan terdiri dari protein (Watanabe, 1988 diacu dalam Suprayudi et al., 1994). Tingginya kandungan protein dipengaruhi oleh spesies lingkungan dan makanan. Ikan gurami yang diamati pada penelitian ini termasuk tipe ikan yang berprotein tinggi diantara protein ikan air tawar lainnya seperti ikan mas (protein 16,O g dan lemak 2,O g), nila (protein 16,17 g dan lemak 0,39 g), dan lele (protein 18,2 $\mathrm{g}$ dan lemak 2,2 g) (Khornsan, 2004).

\section{Kandungan Asam Amino}

Mutu protein dinilai dari perbandingan asam-asam amino yang terkandung di dalam protein tersebut. Pada prinsipnya suatu protein yang dapat menyediakan asam amino esensial dalam suatu perbandingan yang menyamai kebutuhan tubuh sehingga dikatakan mempunyai mutu yang tinggi (Winarno 1997). Kandungan protein ikan relatif besar, yaitu antara 15-25 g/100 g daging ikan. Selain itu, protein ikan terdiri dari asam-asam amino yang hampir semuanya diperlukan oleh tubuh manusia.

Hasil analisis asam amino menggunakan metode hidrolisis asarn dengan HPLC menunjukkan adanya 17 asam amino pada ikan gurami dengan perbedaan ukuran ikan yang diteliti. Asam amino ini terdiri dari 9 asam amino esensial dan 8 asam amino non esensial. Hasil analisis asam amino ikan gurami pada beberapa ukuran ikan dapat dilihat pada Tabel 6. Tabel 6 menunjukkan bahwa diantara 17 asam amino, terdapat lima jenis asam amino yang mendominasi, yaitu asam glutamat, asam aspartat, dan histidin yang termasuk asam amino non esensial sedangkan untuk asam amino esensial yaitu metionin dan leusin. Komposisi asam amino tertinggi terdapat pada ikan gurami dengan ukuran 900-1100 g dan nilai asam amino yang terendah pada ikan gurami kuran 400-500 g. Asam glutamat, asam aspartat, dan histidin merupakan asam amino yang banyak terdapat pada daging ikan gurami yang diteliti. Berdasarkan Tabel 6 diketahui bahwa kadar asam glutamat tertinggi terdapat pada ikan gurarni ukuran $900-1100 \mathrm{~g}$ dengan nilai $14,49 \mathrm{mg} / \mathrm{gram}$ dan yang terendah pada ikan gurami ukuran 400-500 g sebesar $9,48 \mathrm{mg} / \mathrm{gram}$.

Kadar histidin ikan gurami cukup tinggi berkisar 4,28-5,90 mg/gram, histidin merupakan salah satu dari sepuluh asam amino esensial yang dibutuhkan oleh anak-anak dan bayi. Histamin merupakan senyawa turunan dari asam amino histidin yang banyak terdapat pada ikan. Histamin di dalam daging diproduksi oleh enzim yang menyebabkan pemecahan histidin yaitu enzim histidine dekarboksilase. Melalui proses dekarboksilasi (pernotongan gugus karboksil) dihasilkan histamin. Pada orang-orang yang peka, histamin dapat menyebabkan migrain dan meningkatkan tekanan darah. Histamin tidak membahayakan jika dikonsumsi dalam jumlah yang rendah, yaitu $8 \mathrm{mg} / 100$ gram daging ikan. Menurut FDA (Food and Drug Administration) di Amerika Serikat, keracunan histamin akan berbahaya jika seseorang mengonsumsi ikan dengan kandungan histamin yaitu $50 \mathrm{mg} / 100$ gram ikan. Kandungan histamin sebesar $20 \mathrm{mg} / 100$ gram daging ikan akan terjadi jika penanganan ikan dilakukan secara tidak higienis. Gejala keracunan akan muncul apabila kita mengonsumsi ikan dengan kandungan histamin yang berlebih, yaitu dalam jurnlah di atas $70 \mathrm{mg} / 100$ gram daging ikan yang menyebabkan, timbul muntah-muntah, rasa terbakar pada tenggorokan, bibir bengkak, sakit kepala, kejang, mual, muka dan leher kemerah- merahan, gatal-gatal, dan badan lemas (Efendie 2008).

Pada ikan gurarni yang diuji hampir semua jenis asam amino esensial tersebut dihasilkan kecuali triptophan yang dalam hal ini tidak dianalisis, karena mengalami kerusakan pada saat proses hidrolisis asam. Untuk menganalisa asam amino tersebut harus dengan proses hidrolisis basa, dan adapun tidak teridentifiksinya beberapa asam amino diduga karena kandungan asam amino tersebut sangat rendah.

\section{Kandungan Asam Lemak}

Secara umum hasil analisis asam lemak pada daging ikan gurami menunjukkan bahwa daging ikan gurami ukuran kecil, sedang dan besar memiliki 21 jenis asam lemak, (dapat dilihat pada Tabel 7) yang terdiri dari 9 jenis asam lemak jenuh (Saturated Fatty Acid/SAFA) (dapat dilihat pada Tabel 12), 6 asam lemak tak jenuh tunggal (Monounsaturated Fatty Acid/MUFA) (dapat dilihat pada Tabel 15), dan 6 asam lemak tak jenuh jamak (Polyunsaturated Fatty Acid/PUFA) (dapat dilihat pada Tabel 7). Pada Table 7. Kandungan asam lemak jenuh (SAFA) tertinggi pada daging ikan gurami ukuran 
600-800 g, yaitu 37,76 \%, dan terendah pada daging ikan gurami ukuran 900-1100 yaitu 32,70 \% dari total asam lemak ikan. Asam lemak tak jenuh tunggal tertinggi pada daging ikan berukuran 900-1100 g, yaitu 38,59\%, dan terendah pada ikan berukuran 600-800 g, yaitu 36,82\% dari total asam lemak ikan. Asam lemak tak jenuh jamak tertinggi pada daging ikan gurami dengan berukuran 900-1100 g, yaitu 28,15\%, dan terendah pada ikan berukuran 600-800 g, yaitu 22,62\% dari total asam lemak ikan. Keragaman komposisi asam lemak ikan dipengaruhi oleh beberapa faktor, yaitu spesies, pakan, letak geografis, serta umur dan ukuran ikan tersebut (Ozogul dan Ozogul 2005).

Komposisi asam lemak tak jenuh tunggal (MUFA) yang terkandung dalam daging ikan gurami pada ukuran berbeda dapat dilihat pada Tabel 7. Berdasarkan Tabel tersebut, jenis asam lemak didominasi oleh oleat (C18:1), yaitu paling banyak terdapat pada ikan dengan ukuran 900-1100 g, yaitu 35,03 \%, dan terendah pada ikan ukuran 600-800 g, yaitu 33,25\% dari total asam lemak ikan. Nilai ini hampir sama dengan penelitian Moreira et al. (2001), dimana komposisi oleat berkisar antara $39,74-45,23 \%$.

Komposisi asam lemak tak jenuh jamak yang terkandung dalam daging ikan gurami pada berbagai ukuran berbeda dapat dilihat pada Tabel 7. Berdasarkan Tabel tersebut, asam lemak tak jenuh jamak (PUFA) terdiri dari linoleat, Y-linoleat, A-Linoleat, Eicosatrieleat, arachidoleat, dan DHA. Asam lemak tak jenuh jamak (PUFA) ikan gurami didominasi oleh linoleat (C18:2n-6), yaitu tertinggi pada ikan ukuran 900-1100 g, yaitu 21,60\%, dan terendah pada ikan ukuran 600-800 g, yaitu $16,71 \%$ dari total asam lemak ikan. Kandungan Y-linoleat terdapat 2,48-2,71\%, A-linoleat terdapat $1,04-1,11 \%$, eicosatrieleat terdapat $0,82-1,11 \%$, arachidoleat terdapat $0,21-0,28 \%$, dan DHA hanya terdapat $1,19-1,53 \%$ dari total asam lemak, tertinggi pada ikan ukuran 900-1100g, yaitu $28,12 \%$ dari total asam lemak ikan. Menurut Connor et al. (1992), tingginya asam linoleat dapat menghambat laju biosintesis DHA dari asam linolenat. Menurut Crawford (1993), proses biosintesis tersebut akan berjalan lambat, kurang efisien, dan berubah menurut umur, namun hal ini perlu ada penelitian lebih lanjut.

\section{KESIMPULAN}

Ukuran ikan tidak berpengaruh terhadap penampakan dan bau ikan akan tetapi berpengaruh terhadap rasa dan tekstur daging ikan gurami. rasa dan tekstur yang paling baik pada daging ikan gurami terdapat pada ikan ukuran besar (900-1100 g/ekor) yaitu, 8,5 dan 8,1..

Edible portion (bagian ikan yang dapat dimakan) ikan ukuran 900-1100 g, yaitu 53,4 \%, ikan ukuran 600-800 g, yaitu 53,2\%, dan ikan ukuran 400-500 g, yaitu 53,3\%. Processing waste (bagian ikan yang tidak dapat dimakan) ikan ukuran 900-1100 g, yaitu 47,7 \%, ikan ukuran 600-800 g, yaitu $47,0 \%$, dan ikan ukuran 400-500 g, yaitu 46,7\%. Water holding capacity (daya ikat air oleh protein daging) ikan ukuran 900-1100 g, yaitu 28,3\%, ikan ukuran 600-800 g, yaitu 32,4\%, dan ikan ukuran 400-500 g, yaitu 26,0\%.

Komposisi kimia daging ikan meliputi kadar air, abu, protein, dan lemak. Kadar air rata-rata dari ikan ukuran 900-1100 g, 600-800 g, dan 400-500 g, yaitu 72,69\%, 74,20\%, dan 75,55 \%. Kadar abu rata-rata dari ikan ukuran 900-1100 g, 600-800 g, dan 400-500 g, yaitu 0,88\%, 0,90\%, dan 1,05 $\%$. Kadar protein rata-rata dari ikan ukuran 900-1100 g, 600-800 g, dan 400-500 g, yaitu 20,88\%, $18,70 \%$, dan 18,36\%. Kadar lemak rata-rata dari ikan ukuran 900-1100 g, 600-800 g, dan 400-500 g, yaitu $2,70 \%, 2,40 \%$, dan $2,29 \%$.

Berdasarkan hasil analisis asam amino terdapat 5 jenis asam amino yang mendominasi yaitu, asam glutamat, asam aspartat, histidin, metionin, dan leusin. Asam amino yang memiliki jumlah tertinggi yaitu asam glutamat. Ikan gurami dengan ukuran 900-1100 g memiliki asam amino glutamat sebesar $14,49 \mathrm{mg} / \mathrm{g}$ dan asam amino terendah yaitu alanin sebesar $0,72 \mathrm{mg} / \mathrm{g}$. Ikan gurami ukuran 600 $800 \mathrm{~g}$ memiliki kadar asam glutarnat $11,16 \mathrm{mg} / \mathrm{g}$ dan alanin sebesar $0,83 \mathrm{mg} / \mathrm{g}$. Ikan gurami ukuran 400-500 g memiliki kadar asam glutamat sebesar $9,48 \mathrm{mg} / \mathrm{g}$ dan nilai terendah, yaitu alanin sebesar $0,61 \mathrm{mg} / \mathrm{g}$.

Asam lemak jenuh total yang terdiri dari laurat, miristat, palmitat, stearat, penthadecanoat, heptadecanoat, arachidat, heneicosanoat, dan docosanoat, berturut-turut dari ikan dengan ukuran 900$1100 \mathrm{~g}, 600-800 \mathrm{~g}$, dan 400-500 g, yaitu 32,70 \%, 37,76 \% dan 34,30\%. Asam lemak tak jenuh tunggal terdiri dari myritoleat, palmitoleat, heptedecoleat, oleat, eicoeleat, dan erukat, berturut-turut dari ikan yang paling dewasa, yaitu 38,59\%,36,82 \%, dan 37,39 \%. Asam lemak tak jenuh jamak terdiri dari linoleat, Y-linoleat, A-linoleat, eicosatrileat, archidoleat, dan DHA, dengan jumlah total berturut-turut, yaitu $28,12 \%, 22,62 \%$, dan $25,94 \%$.

\section{REKOMENDASI}

Berdasarkan hasil penelitian di atas, maka disarankan untuk dilakukan penelitian lanjut mengenai kandungan gizi ikan gurami yang lebih spesifik seperti kadar kalsium yang terdapat didalam 
tulang ikan gurami yang berperan dalam kesehatan tulang, kadar kolesterol serta enzim yang berperan dalam metabolisme ikan gurami, pemanfaatan ikan gurami tersebut secara komersial, dan konsumsi ikan gurami berukuran besar karena lebih mengandung kandungan gizi yang tinggi.

\section{DAFTAR PUSTAKA}

Bahar B. 2003. Psanduan Praktis Memilih Daging Sapi. Jakarta: PT Gramedia Pustaka Utama.

BPS Provinsi Riau. 2016. Provinsi Riau Dalam Angka 2016. Badan Pusat StatistikProvinsi Riau. Pekanbaru.

Dwi, S. P. 2011. Pengaruh Tingkat Subtitusi Tepung Ikan dengan Tepung Maggot Terhadap Komposisi Kimia Pakan dan Tubuh Ikan Bandeng.Fakultas Ilmu Kelautan dan Perikanan. Universitas Hasanuddin. Makasar.

Estiasih, Teti, 2009. Minyak Ikan (Teknologi dan Penerapannya untuk Pngan dan Kesehatan). Graha Ilmu. Yogyakarta.

Hadiwiyoto, S. 1993. Teknologi Hasil Perikanan. Jilid I. Liberty. Yogyakarta. Kottelat, M., A.J. Whitten, with S.N.

Kartikasari and S. Wirjoadmodjo.1993. Freshwater Fishes of Western Indonesia and Sulawesi. Periplus Edition (HK), Jakarta.

KKP. 2016. Upi-Menengah-Besar. Kementrian Kelautan dan Perikanan Republik Indonesia. Diakses: 31 September 2018. http://kkp.go.id

Linder MC. 1992. Biokimia Nutrisi dan Metabolisme dengan Pemakaian Secara Kimia. Aminuddin P, Penerjemah. Jakarta: UI Press.

Ozogul Y, Ozogul F. 2005. Fatty acid profiles of commercially important fish species from.

Rasyad. F. 2011. Kajian profil asam lemak pada beberapa ikan air tawar hasil budidaya.Skripsi. Universitas Riau. Pkanbaru. 88 hal.

Sudarmadji, S, Bambang dan Suhandi,1997. Prosedur Analisis Untuk Bahan Makanan dan Pertanian.Li berti.Yogyakarta. 132.

Suprayudi MA, Setiawati M, Mokoginta I. 1994. Pengaruh rasio protein energi yang berbeda terhadap pertumbuhan ikan gurami (Osphronemus gouramy) [laporan penelitian]. Bogor: Fakultas Perikanan dan Ilmu Kelautan, Institut Pertanian Bogor.

Suwetja, I. K. 2011. Biokimia hasil perikanan. Jakarta, Media Prima Aksara.

Suzuki T. 1981. Fish and Krill Protein Processing Technology. London: Applied Science Publisher LTD.

Winarno. 1997. Kimia Pangan dan Gizi. Jakarta: PT. Gramedia Pustaka Utama.

Zaitzev, V.I, Lagunov. T, Makarova. I, Minder dan V, Podsevalov. 1969. Fish Curing and Processing. Mir Pulishers.Moskow. 